\title{
Regioselective alkynylation followed by Suzuki coupling of 2,4-dichloroquinoline: Synthesis of 2-alkynyl-4-arylquinolines
}

\author{
Ellanki A. Reddy ${ }^{1,2}$, Aminul Islam ${ }^{1}$, K. Mukkanti ${ }^{2}$, Venkanna Bandameedi ${ }^{1}$, \\ Dipal R. Bhowmik ${ }^{1}$ and Manojit Pal ${ }^{*}, 3$
}

\section{Preliminary Communication}

\begin{abstract}
Address:
${ }^{1}$ Dr. Reddy's Laboratories Limited, Bollaram Road, Miyapur, Hyderabad 500049, Andhra Pradesh, India, ${ }^{2}$ Chemistry Division, Institute of Science and Technology, JNT University, Kukutpally, Hyderabad 500072, Andhra Pradesh, India and ${ }^{3}$ New Drug Discovery, R\&D Center, Matrix Laboratories Ltd., Anrich Industrial Estate, Bollaram, Jinnaram Mandal, Medak District, Andra Pradesh 502 325, India (present address: Institute of Life Science, University of Hyderabad Campus, Gachibowli, Hyderabad 500 046, Andhra Pradesh, India)

Email:

Manojit Pal ${ }^{*}$ - manojitpal@rediffmail.com

${ }^{*}$ Corresponding author

Keywords:

alkyne; boronic acid; catalysis; 2,4-dichloroquinoline; palladium; water
\end{abstract}

Beilstein Journal of Organic Chemistry 2009, 5, No. 32. doi:10.3762/bjoc.5.32

Received: 16 April 2009

Accepted: 19 June 2009

Published: 01 July 2009

Associate Editor: I. Marek

(๑) 2009 Reddy et al; licensee Beilstein-Institut. License and terms: see end of document.

\section{Abstract}

A two step synthesis of 2-alkynyl-4-arylquinolines has been accomplished via $\mathrm{Pd} / \mathrm{C}$-mediated regioselective C-2 alkynylation of 2,4-dichloroquinoline in water followed by Suzuki coupling at C-4 of the resulting 4-chloro derivative.

\section{Introduction}

2-Alkynyl pyridine and its benzo (i.e. quinoline) derivative possessing an aryl group at the C-4 position (A, Figure 1) have attracted considerable interest due to their utility in the development of compounds of potential pharmacological interest [1-3].

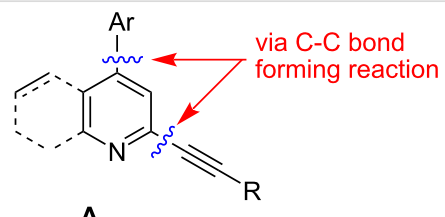

A

Figure 1: 2-Alkynyl-4-aryl pyridine and its benzo derivative.
2-Alkenyl/alkynylquinolines, have been reported to possess anti-retroviral properties [4]. Only few methods are known for the synthesis of $\mathbf{A}$. Considering the possible $\mathrm{C}-\mathrm{C}$ bond forming reactions on a pyridine/quinoline ring (Figure 1), the synthesis of $\mathbf{A}$ can be carried out following two main strategies e.g. (a) arylation at $\mathrm{C}-4$ followed by alkynylation at $\mathrm{C}-2$ or (b) alkynylation at C-2 followed by arylation at C-4. Methodologies based on strategy ' $a$ ' have been reported earlier. For example, Sonogashira coupling of a terminal alkyne with 2-chloro-4-aryl substituted quinoline [3] in the presence of $\left(\mathrm{PPh}_{3}\right)_{2} \mathrm{PdCl}_{2}-\mathrm{CuI}$ or treatment of 4-aryl pyridine- $N$-oxide with alkynyl Grignard [5] provided the required quinoline or 


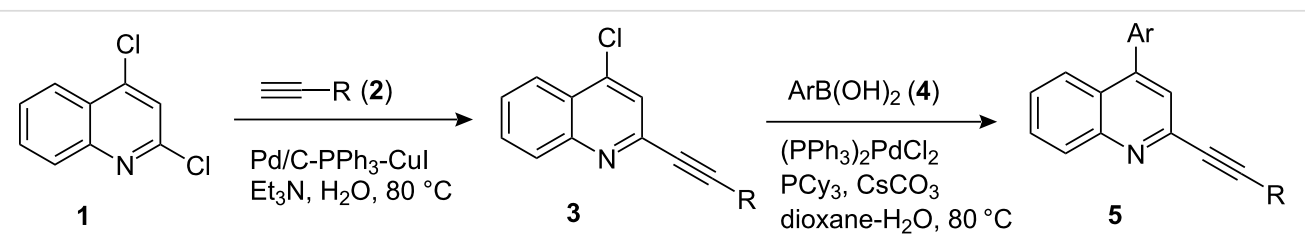

Scheme 1: Sequential synthesis of 2-alkynyl-4-arylquinolines from 2,4-dichloroquinoline under palladium catalysis.

pyridine derivatives, respectively. Notably, synthesis of $\mathbf{A}$ following the strategy ' $b$ ' has not been explored. In our effort towards the synthesis of quinoline derivatives of potential biological significance we have reported $\mathrm{Pd} / \mathrm{C}$-mediated regioselective C-2 alkynylation of 2,4-dichloroquinoline in water [6]. However, only one example of regioselective C-2 alkynylation was reported and no detailed study has been carried out previously. Herein we report the preparation of a series of 2-alkynyl4-chloroquinoline (3) followed by successful Suzuki coupling at C-4 of compound 3 leading to the corresponding 4-arylated derivatives (5) in good yields (Scheme 1). To the best of our knowledge this is the first synthesis of 2-alkynyl-4arylquinolines following such a strategy.

\section{Results and Discussion}

A number of 2-alkynyl-4-chloroquinolines (3) were prepared via coupling of 2,4-dichloroquinoline (1) in the presence of $10 \% \mathrm{Pd} / \mathrm{C}\left(10 \mathrm{~mol}^{\%}\right), \mathrm{PPh}_{3}(20 \mathrm{~mol} \%)$ and $\mathrm{CuI}(5 \mathrm{~mol} \%)$ as a catalyst system in water. The results are presented in Table 1. Both aryl and alkyl substituted terminal alkynes participated well in this $\mathrm{C}-\mathrm{C}$ bond forming reaction to afford the desired product in good yields. The reaction was found to be highly selective for mono-substituted product and no dialkynylated product was isolated from the reaction mixture. Moreover, the reaction displayed good regioselectivity for C-2 alkynylation though the formation of C-4 alkynylated product cannot be ruled out completely. Regioselectivity for C-2 alkynylation was confirmed by NOE (Nuclear Overhauser Effect) studies using compound 3a. Irradiation of protons of the benzene ring attached to the alkynyl group resulted in enhancement of the singlet at $\delta 8.03$ assigned to the $\mathrm{C}-3$ hydrogen of the quinoline ring. If the alkyne was at $\mathrm{C}-4, \mathrm{NOE}$ enhancement at $\mathrm{C}-5$ is expected in addition to C-3. It is note worthy that the use of the Sonogashira coupling or its modified form has been employed for the preparation of 2-alkynylquinolines or related derivatives earlier [7-17].

Next, in order to prepare 2-alkynyl-4-arylquinolines (5) we planned to exploit the reactivity of chloro group of $\mathbf{3}$ towards Suzuki arylation reaction. Accordingly, a variety of arylboronic acids were coupled with $\mathbf{3}$ and results of this study are summarized in Table 2. The Suzuki reaction was carried out using arylboronic acids in the presence of $\left(\mathrm{PPh}_{3}\right)_{2} \mathrm{PdCl}_{2}$ as a catalyst, $\mathrm{CsCO}_{3}$ as a base, tricyclohexyl phophine, $\left(\mathrm{PCy}_{3}\right)$ as a ligand in dioxane-water at $80{ }^{\circ} \mathrm{C}$. The arylboronic acids used in this reaction include phenylboronic acid (entries 1-6, Table 2), 3-methoxyphenylboronic acid (entry 7, Table 2) and 4-fluorophenyl boronic acid (entry 8 , Table 2), all of which participated well in the coupling reaction with 3 . A number of 2-alkynyl-4arylquinolines (5) were prepared in good to excellent yields without affecting the alkynyl substituents present in compound 3 .

The reaction mechanism of the present stepwise $\mathrm{C}-\mathrm{C}$ bond forming reactions consisting of alkynylation followed by arylation is shown in Scheme 2. The $\mathrm{Pd} / \mathrm{C}-\mathrm{Cu}$ mediated coupling of
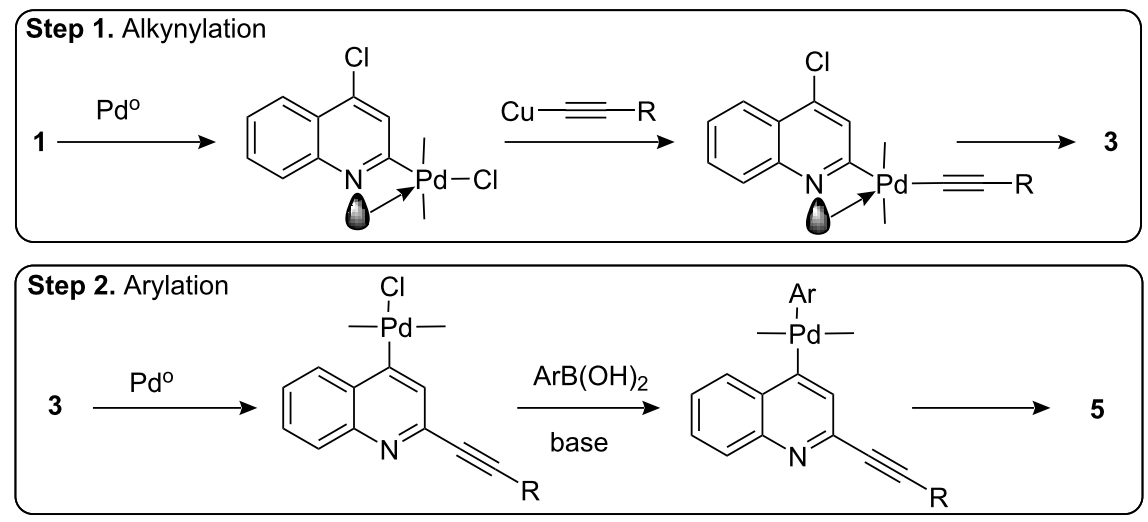

Scheme 2: The reaction mechanism of stepwise $\mathrm{C}-\mathrm{C}$ bond forming reactions. 


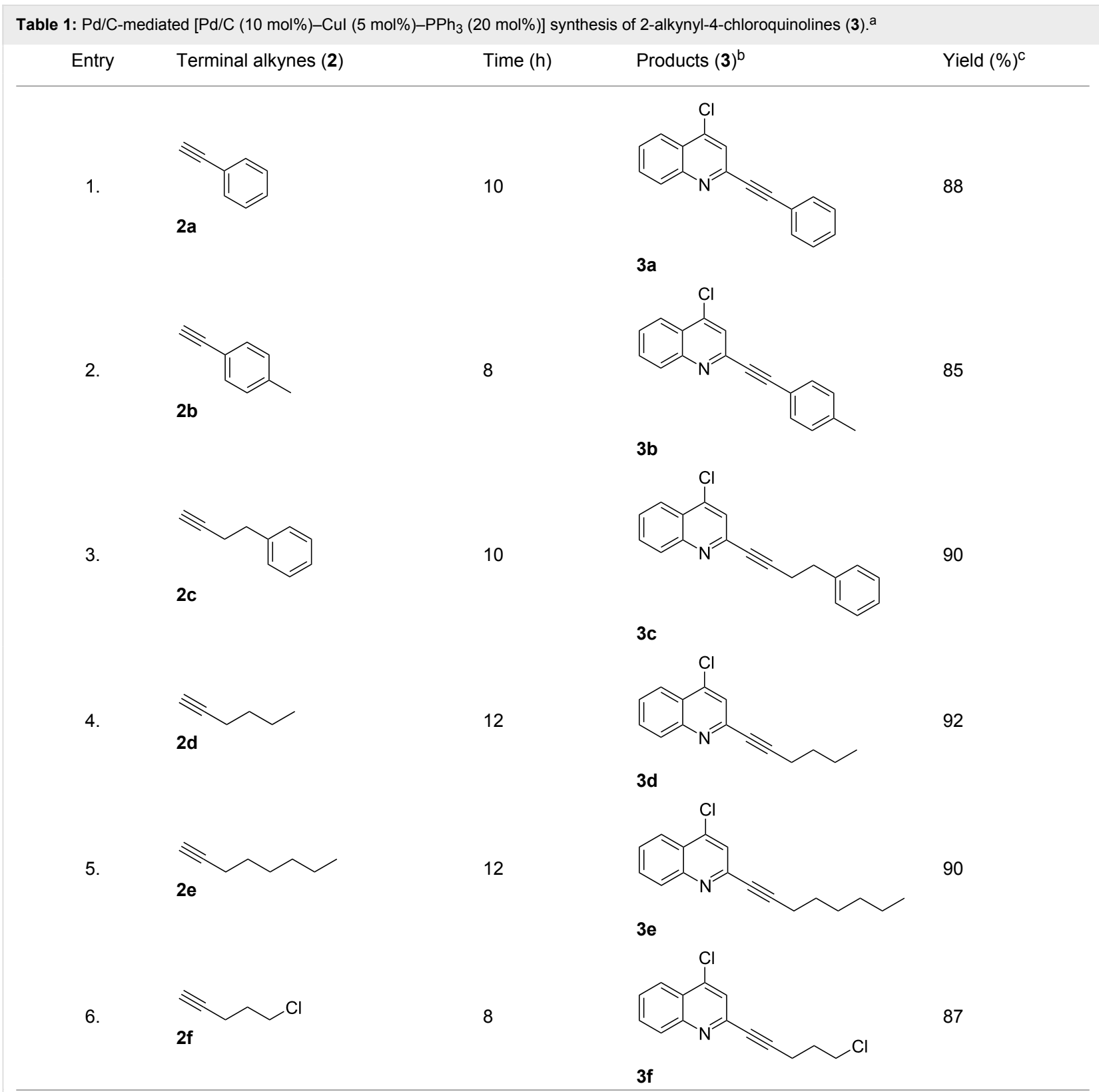

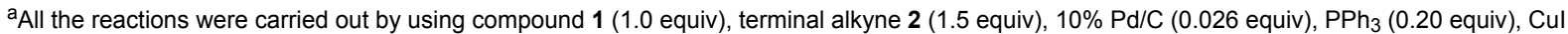
( 0.05 equiv), and $\mathrm{Et}_{3} \mathrm{~N}\left(3.0\right.$ equiv) at $80^{\circ} \mathrm{C}$.

bldentified by ${ }^{1} \mathrm{H}$ NMR, IR, and MS.

'Isolated yields.

2,4 dichloroquinoline (1) with terminal alkynes (2) in water proceeds via normal Sonogashira pathway [6]. Due to the presence of electronegative nitrogen atom the chloro group at the azomethine carbon is more susceptible to undergo oxidative addition with $\operatorname{Pd}(0)$ than chloro group at $\mathrm{C}-4$. Moreover, the coordination of quinoline nitrogen to the palladium $[18,19]$ controls the regioselectivity in alkynylation of 2,4dichloroquinoline at C-2 position. The 2-alkynyl-4chloroquinolines 3 thus formed then undergo Suzuki reaction in the next step. Oxidative addition of $\mathrm{Pd}^{0}$ generated in situ to compound $\mathbf{3}$ followed by trans-organometallation of the resultant aryl-palladium complex formed with arylboronic acids provides the desired compound $\mathbf{5}$.

\section{Conclusions}

In conclusion, a two-step method consisting of alkynylation followed by arylation has been developed for the synthesis of 2-alkynyl-4-arylquinolines. The alkynylation step involved $\mathrm{Pd} /$ $\mathrm{C}-\mathrm{Cu}$ mediated regioselective C-2 alkynylation of 2,4dichloroquinoline in water to afford 2-alkynyl-4- 
chloroquinoline. The arylation step is a Pd-mediated (Suzuki) coupling of 2-alkynyl-4-chloro derivative with arylboronic acids in aqueous media to give the target compounds. The process is amenable to the diversity-oriented synthesis of quinoline derivatives of potential pharmacological significance and may therefore find wide usage in organic/medicinal chemistry.

Table 2: Synthesis of 2-alkynyl-4-arylquinolines (5).

Arylboronic acid (4)

Product $^{\mathrm{a}}(\mathbf{5})$

Time (h) Yield $(\%)^{\mathrm{b}}$

1.

$3 e$

phenylboronic acid (4a)

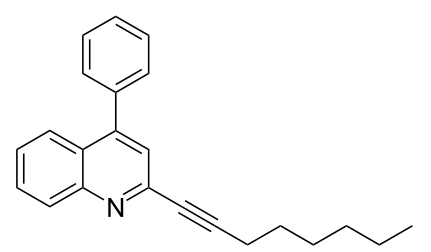

$5 a$<smiles>Cc1ccc(C#Cc2cc(-c3ccccc3)c3ccccc3n2)cc1</smiles>

3

$5 b$<smiles>C(#Cc1cc(-c2ccccc2)c2ccccc2n1)CCc1ccccc1</smiles>

2

87

$5 c$<smiles>CCCCC#Cc1cc(-c2ccccc2)c2ccccc2n1</smiles>

5d<smiles>C(#Cc1cc(-c2ccccc2)c2ccccc2n1)c1ccccc1</smiles>

2

84

$5 e$<smiles>ClCCCC#Cc1cc(-c2ccccc2)c2ccccc2n1</smiles> 
Table 2: Synthesis of 2-alkynyl-4-arylquinolines (5). (continued)

7.

8.
$3 a$

$3 a$ 3-methoxy-phenylboronic acid

(4b)<smiles>COc1cccc(-c2cc(C#Cc3ccccc3)nc3ccccc23)c1</smiles>

$5 \mathrm{~g}$<smiles>Fc1ccc(-c2cc(C#Cc3ccccc3)nc3ccccc23)cc1</smiles>

2

86

$5 h$

adentified by ${ }^{1} \mathrm{H}$ NMR, IR, and MS

blsolated yields.

\section{Experimental}

General Procedure for the preparation of compound 5: A mixture of alkyne $3(1.0 \mathrm{mmol})$ and $\left(\mathrm{PPh}_{3}\right)_{2} \mathrm{PdCl}_{2}(0.05 \mathrm{mmol})$ in dioxane $(5.0 \mathrm{~mL})$ was stirred for $10 \mathrm{~min}$ under nitrogen at room temperature and then heated to $80^{\circ} \mathrm{C}$. To this mixture was added a solution of $\mathrm{PCy}_{3}(0.05 \mathrm{mmol})$ and $\mathrm{CsCO}_{3}(3.5 \mathrm{mmol})$ dissolved in water $(3.0 \mathrm{~mL})$ and arylboronic acid $(1.5 \mathrm{mmol})$ dissolved in dioxane $(3.0 \mathrm{~mL})$ at the same temperature. The mixture was stirred at $80^{\circ} \mathrm{C}$ according to the time indicated in Table 2. After completion of the reaction the mixture was cooled to room temperature, concentrated under vacuum and the residue was extracted with EtOAc $(3 \times 30 \mathrm{~mL})$. The organic layers were collected, combined, washed with cold water $(3 \times$ $30 \mathrm{~mL}$ ), dried over anhydrous $\mathrm{Na}_{2} \mathrm{SO}_{4}$ and concentrated under vacuum. The crude product was purified by column chromatography on silica gel, using light petroleum ether $\left(60-80^{\circ} \mathrm{C}\right)$ ethyl acetate to afford the desired product. Spectral data for selected compounds; Compound 5a; light brown gum, Rf (20\% ethyl acetate/n-hexane) $0.21 ;{ }^{1} \mathrm{H} \mathrm{NMR}\left(\mathrm{CDCl}_{3}, 400 \mathrm{MHz}\right) \delta$ $8.14(\mathrm{~d}, J=8.0 \mathrm{~Hz}, 1 \mathrm{H}), 7.85(\mathrm{~d}, J=8.0 \mathrm{~Hz}, 1 \mathrm{H}), 7.69(\mathrm{t}, J=$ $7.8 \mathrm{~Hz}, 1 \mathrm{H}), 7.50-7.41(\mathrm{~m}, 7 \mathrm{H}), 2.49(\mathrm{t}, J=7.0 \mathrm{~Hz}, 2 \mathrm{H})$, 1.69-1.21 (m, 8H), 0.91-0.8 (m, 3H); IR ( $\mathrm{cm}^{-1}$, neat) 2927 , 2225, 1587, 1543, 1357; m/z (ES Mass) $314(\mathrm{M}+1,100 \%) ;{ }^{13} \mathrm{C}$ $\mathrm{NMR}\left(\mathrm{CDCl}_{3}, 50 \mathrm{MHz}\right) 148.5,143.6,137.5$ (2C), 129.6 (3C), 128.4 (2C), 126.7 (2C), 125.5 (3C), 124.3, 92.2, 81.0, 76.3, $31.3,29.6,28.0,24.6,22.5$; HRMS (ESI): calcd for $\mathrm{C}_{23} \mathrm{H}_{23} \mathrm{~N}$ $(\mathrm{M}+\mathrm{H})^{+} 314.1909$, found 314.1896. Compound 5b, low melting solid, $\mathrm{R}_{\mathrm{f}}(20 \%$ ethyl acetate/n-hexane $) 0.28 ;{ }^{1} \mathrm{H} \mathrm{NMR}\left(\mathrm{CDCl}_{3}\right.$, $400 \mathrm{MHz}) \delta 8.20(\mathrm{~d}, J=7.8 \mathrm{~Hz}, 1 \mathrm{H}), 7.87(\mathrm{~d}, J=7.8 \mathrm{~Hz}, 1 \mathrm{H})$,
7.75-7.71 (m, 1H), 7.56-7.47 (m, 9H), 7.25-7.17 (m, 2H), 2.38 (s, 3H); IR ( $\mathrm{cm}^{-1}$, neat) 2924, 2216, 1583, 1541; m/z (ES Mass) $320(\mathrm{M}+1,100 \%) ;{ }^{13} \mathrm{C} \mathrm{NMR}\left(\mathrm{CDCl}_{3}, 50 \mathrm{MHz}\right) 148.6,148.5$, 143.2 (2C), 139.3 (2C), 137.3 (2C), 134, 132, 129.5 (3C), 129.3 (2C), 126.9 (2C), 125.6 (2C), 124.4, 118.9, 90.2, 88.8, 29.0; HRMS (ESI): calcd for $\mathrm{C}_{24} \mathrm{H}_{17} \mathrm{~N}(\mathrm{M}+\mathrm{H})^{+} 320.1439$, found 320.1454 .

\section{Supporting Information}

\section{Supporting Information File 1}

Spectral data of 2-alkynyl-4-arylquinolines $\mathbf{5} \mathbf{c}-\mathbf{h}$. [http://www.beilstein-journals.org/bjoc/content/ supplementary/1860-5397-5-32-S1.doc]

\section{Acknowledgments}

The authors thank Dr. V. Dahanukar and Mr. A. Mukherjee for their encouragement and the analytical group for spectral data. Mr. E.A.R. thanks CPS-DRL, Hyderabad, India for allowing him to pursue this work as a part of his Ph.D. program.

\section{References}

1. Godel, T.; Hoffmann, T.; Schnider, P.; Stadler, H. Preparation of 4-phenylpyridines as neurokinin-1 receptor antagonists. World patent application WO 2002016324 A1, 2002. Chem. Abstr. 2002, 136, 216655.

2. Prostakov, N. S.; Mathew, K. J.; Kurichev, V. A. Khimiya Geterotsiklicheskikh Soedinenii 1967, 5, 876-879. Chem. Abstr. 1968, 69, 18982. 
3. Angibaud, P. R.; Venet, M. G.; Pilatte, I. N. C. World Patent Application WO 2002024682 A1, 2002.

Chem. Abstr. 2002, 136, 279469

4. Fakhfakh, M. A.; Fournet, A.; Prina, E.; Mouscadet, J.-F.; Franck, X.; Hocquemiller, R.; Figadère, B. Bioorg. Med. Chem. 2003, 11, 5013-5023. doi:10.1016/j.bmc.2003.09.007

5. Andersson, H.; Almqvist, F.; Olsson, R. Org. Lett. 2007, 9, 1335-1337. doi:10.1021/ol070184n

6. Reddy, E. A.; Barange, D. K.; Islam, A.; Mukkanti, K.; Pal, M. Tetrahedron 2008, 64, 7143-7150. doi:10.1016/j.tet.2008.05.097

7. Nolan, J. M.; Comins, D. L. J. Org. Chem. 2003, 68, 3736-3738. doi:10.1021/jo034122w

8. Elangoven, A.; Chen, T.-Y.; Chen, C.-Y.; Ho, T.-I. Chem. Commun. 2003, 2146-2147. doi:10.1039/b305943j

9. Seck, M.; Franck, X.; Hocquemiller, R.; Figadère, B.; Peyrat, J.-F.; Provot, O.; Brion, J.-D.; Alami, M. Tetrahedron Lett. 2004, 45, 1881-1884. doi:10.1016/j.tetlet.2004.01.019

10. Rodriguez, J. G.; de los Rios, C.; Lafuente, A. Tetrahedron 2005, 61, 9042-9051. doi:10.1016/j.tet.2005.07.043

11. Toyota, M.; Komori, C.; Ihara, M. J. Org. Chem. 2000, 65, 7110-7113. doi:10.1021/jo000816i

12. Ciufolini, M. A.; Mitchell, J. W.; Roschangar, F. Tetrahedron Lett. 1996, 37, 8281-8284. doi:10.1016/0040-4039(96)01937-5

13. Yamanaka, H.; Shiraiwa, M.; Edo, K.; Sakamoto, T. Chem. Pharm. Bull. 1979, 27, 270-273.

14. Belmont, P.; Andrez, J.-C.; Allan, C. S. M. Tetrahedron Lett. 2004, 45, 2783-2786. doi:10.1016/j.tetlet.2004.02.022

15. Beletskaya, I. P.; Latyshev, G. V.; Tsvetkov, A. V.; Lukashev, N. V. Russ. Chem. Bull. 2004, 53, 189-193. doi:10.1023/B:RUCB.0000024849.57521.49 (See for the synthesis of 6-alkynylquinolines.)

16. Belmont, P.; Belhadj, T. Org. Lett. 2005, 7, 1793-1795. doi:10.1021/ol050380z

17. Tiano, M.; Belmont, P. J. Org. Chem. 2008, 73, 4101-4109. doi:10.1021/jo800249f

18. Shiota, T.; Yamamori, T. J. Org. Chem. 1999, 64, 453-457. doi:10.1021/jo981423a

19. Legros, J.-Y.; Primault, G.; Fiaud, J.-C. Tetrahedron 2001, 57, 2507-2514. doi:10.1016/S0040-4020(01)00076-X

\section{License and Terms}

This is an Open Access article under the terms of the Creative Commons Attribution License

(http://creativecommons.org/licenses/by/2.0), which permits unrestricted use, distribution, and reproduction in any medium, provided the original work is properly cited.

The license is subject to the Beilstein Journal of Organic Chemistry terms and conditions:

(http://www.beilstein-journals.org/bjoc)

The definitive version of this article is the electronic one which can be found at: doi:10.3762/bjoc.5.32 